\title{
PENGARUH PEMBERIAN FORMULA ENTERAL BERBAHAN DASAR LABU KUNING (Cucurbita moschata) TERHADAP KADAR GLUKOSA DARAH POSTPRANDIAL TIKUS DIABETES MELITUS
}

\author{
Izzaty Izzul Hawa, Etisa Adi Murbawani*)
}

Program Studi Ilmu Gizi Fakultas Kedokteran Universitas Diponegoro

Jl.Dr.Sutomo No.18, Semarang, Telp (024) 8453708, Email : gizifk@undip.ac.id

\begin{abstract}
Background : Postprandial hyperglycemia is a condition that is often appears on with diabetes. Nutrition therapy for patients with diabetes melitus can be given by using enteral therapy. Pumpkin (Cucurbita moschata) is one of traditional foods that has anti-diabetic and anti-hyperglycemia effect and can be formed into enteral formula. Polysaccharides and pectin mainly found in pumpkin are claimed can decrease blood glucose levels and control glycemic level. This study aim to determine the effect pumpkin based of enteral formula on postprandial blood glucose levels of diabetic rats.

Methods : This study was a true experimental with pre-post test group design. The subjects were 14 male rats Sprague Dawley aged 9 weeks, weight 160-260 grams; then divided into 2 groups randomly. All subjects were injected intraperitoneally by $65 \mathrm{mg} / \mathrm{kg}$ weight of Streptozotocin and $230 \mathrm{mg} / \mathrm{kg}$ weight of nicotinamides to obtain diabetic condition. The treatment group were given pumpkin based of enteral formula and the control group were given diabetasol in dosage $20 \mathrm{~g} / \mathrm{kg}$ body weight for each rat. Blood glucose level was measured before and 2 hours after oral administration of enteral formula. This study was done in 1 day at University Centre of Food and Nutrition Laboratory, Gadjah Mada University, Yogyakarta. Statistical analysis was done by using independent t-test and paired t-test methods.

Result : Delta blood glucose in 2 groups are signficantly difference $(p=0.000) ;$ which the treatment group lower than control group $(5.09 \pm 0.31 \mathrm{mg} / \mathrm{dl})$. Postprandial blood glucose between 2 groups $(p=0.605)$ are not significantly difference.

Conclusion : Pumpkin based of enteral formula in dosage $20 \mathrm{~g} / \mathrm{kg}$ body weight has no significant effect on postprandial blood glucose levels of diabetic rats; but there was a significant difference on $\Delta$ blood glucose level of the rats.
\end{abstract}

Keywords: Cucurbita moschata, enteral formula, postprandial blood glucose

\section{ABSTRAK}

Latar belakang :. Hiperglikemia postprandial merupakan keadaan yang sering dialami penderita DM. Penderita DM dapat diberi terapi gizi berupa nutrisi enteral. Labu kuning (Cucurbita moschata) merupakan salah satu pangan tradisional bersifat antidiabetik dan antihiperglikemia yang dapat dijadikan bahan formula enteral. Kandungan polisakarida dan pektin diklaim mampu menurunkan kadar glukosa darah dan mengontrol kadar glikemik. Tujuan penelitian ini mengetahui pengaruh formula enteral berbahan dasar labu kuning terhadap kadar glukosa darah postprandial tikus diabetes.

Metode : Penelitian ini merupakan jenis penelitian true experimental with pre-post test group esign. Subjek sebanyak 14 ekor tikus jantan galur Sprague dawley berumur 9 minggu, berat badan 160-260 gram; dibagi menjadi 2 kelompok secara acak sederhana. Sebelumnya subjek dibuat DM dengan induksi Streptozotocin $65 \mathrm{mg} / \mathrm{kg}$ berat badan dan nikotinamida $230 \mathrm{mg} / \mathrm{kg}$ berat badan secara intraperitoneal. Kelompok perlakuan diberi formula enteral labu kuning sedangkan kelompok kontrol diberi diabetasol $20 \mathrm{~g} / \mathrm{kg}$ bb/ekor. Kadar glukosa darah diambil sebelum dan 2 jam setelah diberi formula enteral. Penelitian ini dilakukan selama 1 hari di Laboratorium Pangan dan Gizi Pusat Antar Universitas, Universitas Gadjah Mada Yogyakarta. Analisis statistik dilakukan menggunakan Independent t-test, dan Paired t-test.

Hasil : Delta glukosa darah pada 2 kelompok mengalami perbedaan bermakna $(p=0.000)$ yaitu kelompok perlakuan lebih rendah dibandingkan kelompok kontrol $(5.09 \pm 0.31 \mathrm{mg} / \mathrm{dl})$. Sedangkan kadar glukosa darah postprandial antara 2 kelompok tidak terdapat perbedaan bermakna $(p=0.605)$.

Simpulan : Pemberian formula enteral labu kuning sebanyak $20 \mathrm{~g} / \mathrm{kg}$ berat badan tidak memiliki pengaruh signifikan terhadap kadar glukosa darah postprandial tikus diabetes melitus. Akan tetapi, berpengaruh bermakna terhadap $\Delta$ glukosa darah.

Kata kunci : Cucurbita moschata, formula enteral, glukosa darah postprandial

\section{PENDAHULUAN}

Diabetes Melitus (DM) termasuk dalam kategori penyakit metabolik ditandai adanya peningkatan kadar gula darah yang diakibatkan oleh gangguan sekresi insulin dan/atau kerja insulin. ${ }^{1}$ Persentase penderita DM di dunia kira kira $4 \%$ dari 
total populasi dan diperkirakan akan meningkat menjadi $5,4 \%$ di tahun 2025 . Tahun 2030 penderita DM di negara maju mencapai 48 juta sedangkan di negara berkembang mencapai 82 juta orang. ${ }^{2}$ Berdasarkan Riskesdas 2013 persentase DM meningkat $1 \%$ dari tahun 2007 menjadi $2,1 \%$ di tahun 2013. Sedangkan prevalensi DM di Jawa Tengah sebesar $1,6 \% .^{3}$

Hiperglikemia merupakan keadaan yang sering dialami penderita DM. Penyebabnya terjadi peningkatan glukosa darah setelah makan atau postprandial. Hiperglikemia postprandial berkaitan dengan risiko perkembangan penyakit kardiovaskuler, retinopati, kanker pankreas, serta perubahan fungsi kognitif pada lansia, khususnya pada penderita DM tipe 2. Salah satu pengobatan dalam mengontrol glukosa darah postprandial yaitu mengkonsumsi makanan yang mengandung indeks glikemi rendah serta tinggi serat. ${ }^{4}$

Pemberian gizi penderita DM perlu diperhatikan, salah satunya dengan terapi enteral agar tidak terjadi overfeeding. Terapi enteral merupakan pemberian makanan untuk tujuan kesehatan khusus baik melalui oral nutritional supplements (ONS) maupun tube feeding. ${ }^{5}$ Indikasi pemberian makanan secara enteral yaitu kemampuan fungsi traktus gastrointestinal dan kapasitas absorbsi yang cukup serta ketidakmampuan mengkonsumsi zat gizi melalui oral secara total atau sebagian. Pemberian makanan secara enteral memiliki dampak komplikasi infeksi lebih sedikit dibandingkan parenteral. ${ }^{6}$

Formula enteral terdiri dari berbagai jenis, salah satunya formula enteral standar. Syarat formula enteral standar yaitu kandungan energi \pm $1.0-1.2 \mathrm{kkal} / \mathrm{ml}$, karbohidrat 40-60\%, lemak 30$40 \%$, dan protein $12-20 \%$. $^{7}$ Formula enteral standar buatan rumah sakit biasanya berbentuk cair atau diblender dan diberikan kepada pasien yang tidak dapat mengkonsumsi makanan dalam bentuk padat. Saat ini belum terdapat formula enteral rumah sakit berbahan dasar pangan tradisional yang berpotensi antihiperglikemia juga antidiabetes.

Labu kuning merupakan satu dari banyak pangan tradisional yang bersifat antidiabetik dan antihiperglikemia. ${ }^{8}$ Labu kuning mengandung serat larut pektin dan senyawa bioaktif seperti protein, peptida, polisakarida, sterol, dan asam para aminobenzoat. ${ }^{9}$ Kandungan polisakarida dilaporkan dapat meningkatkan kadar serum insulin, dan toleransi glukosa, sehingga menurunkan kadar glukosa darah. Penelitian di China tahun 2013 melaporkan pemberian ekstrak labu kuning 75 $\mathrm{mg} / \mathrm{kg}$ berat badan kelinci yang mengandung polisakarida selama 21 hari dapat meningkatkan kontrol glukosa darah, serta memperbaiki sel pankreas. ${ }^{10}$ Pektin disebutkan dapat mengontrol kadar glikemik karena memiliki sifat mampu membentuk gel. ${ }^{11}$

Penambahan tempe dilakukan untuk memenuhi syarat formula enteral. Tempe merupakan sumber protein yang tinggi. Setiap 100 gram tempe mengandung 19 gram protein. Belum terdapat penelitian sebelumnya terkait penggunaan labu kuning sebagai bahan dasar formula enteral dan diberikan kepada pasien DM. Berdasarkan latar belakang tersebut akan dilakukan penelitian pemberian formula enteral berbahan dasar labu kuning dan tempe untuk menurunkan kadar glukosa darah postprandial tikus DM.

\section{METODE PENELITIAN}

Ruang lingkup keilmuan penelitian ini adalah gizi biomedik dengan desain penelitian true experimental with pre-post test group design. Sebanyak 14 ekor tikus putih jantan galur Sprague dawley berumur 9 minggu dengan berat badan 160 - 260 gram yang ditempatkan di Laboratorium Pangan dan Gizi Pusat Antar Universitas (PAU) Universitas Gadjah Mada Yogyakarta. Tikus diukur berat badan guna mengetahui termasuk faktor inklusi atau tidak kemudian diaklimatisasi selama 3 hari. Setelah aklimatisasi tikus dibagi menjadi 2 kelompok secara acak sederhana. Perhitungan jumlah sampel minimal menggunakan rumus WHO dimana setiap kelompok minimal terdiri dari 5 ekor hewan coba. ${ }^{12}$ Selanjutnya ditambah 2 ekor tiap kelompok untuk meminimalisir terjadinya eksklusi. Sehingga didapatkan 7 ekor tiap kelompok. Kriteria inklusi sampel yaitu kadar glukosa darah awal $<110$ $\mathrm{mg} / \mathrm{dl}$ dan glukosa darah setelah diinduksi STZ $\geq$ $200 \mathrm{mg} / \mathrm{dl}$, dan tikus aktif bergerak serta tidak cacat. Sedangkan kriteria eksklusi sampel yaitu terjadi perubahan berat badan $>10 \%$ sebelum perlakuan, tampak sakit dan tidak bergerak aktif, dan tikus mati selama perlakuan.

Variabel tergantung dalam penelitian ini adalah kadar glukosa darah postprandial tikus, sedangkan variabel bebas yaitu $20 \mathrm{~g} / \mathrm{kg}$ berat badan formula enteral berbahan dasar labu kuning dan 20 $\mathrm{g} / \mathrm{kg}$ berat badan formula enteral komersial khusus DM. ${ }^{13}$ Galur, umur, jenis kelamin, dan pakan hewan coba merupakan variabel terkontrol dalam penelitian ini.

Formula enteral berbahan dasar labu kuning terbuat dari daging buah labu kuning yang telah dicampur dengan tempe, tepung beras dan minyak kedelai. Pembuatan formula enteral labu kuning yaitu daging buah labu kuning dan tempe dipotong kecil dan tipis kemudian dikeringkan menggunakan 
oven dengan suhu $40^{\circ} \mathrm{C}$ selama 3 jam. Setelah itu masing-masing labu kuning dan tempe dimasukkan ke dalam food processor hingga menjadi bentuk serbuk. Campurkan $65 \%$ serbuk labu kuning, $20 \%$ serbuk tempe, $13 \%$ tepung beras, dan $2 \%$ minyak kedelai. Formula enteral labu kuning diberikan untuk kelompok perlakuan. Sedangkan formula enteral kelompok kontrol diberi formula khusus diabetes yaitu diabetasol. Pemberian formula enteral baik labu kuning maupun diabetasol sebanyak $20 \mathrm{~g} / \mathrm{kg}$ berat badan dalam $83 \mathrm{ml}$ air $/ \mathrm{kg}$ berat badan selama 1 hari.

Tikus diaklimatisasi menggunakan kandang individu selama 3 hari dengan suhu ruang berkisar $25-28^{0} \mathrm{C}$ dan siklus pencahayaan 12 jam setiap harinya. Selama aklimatisasi tikus diberi pakan standar berupa AIN-93 M dan air minum secara ad libitum.

Tabel 1. Komposisi pakan standar AIN-93M ${ }^{14}$

\begin{tabular}{ll}
\hline Komposisi & g/kg asupan \\
\hline Pati jagung & 465.692 \\
Kasein ( $\geq 85$ protein) & 140.000 \\
Dekstrin pati jagung & 155.000 \\
Sukrosa & 100.000 \\
Minyak kedelai & 40.000 \\
Serat & 50.000 \\
Mineral mix & 35.000 \\
Vitamin mix & 10.000 \\
\hline
\end{tabular}

Setelah aklimatisasi masing-masing tikus diinduksi Streptozotocin (STZ) $65 \mathrm{mg} / \mathrm{kg}$ berat badan dan nikotinamida $230 \mathrm{mg} / \mathrm{kg}$ berat badan secara intraperitoneal. Dilakukan pemeriksaan kadar glukosa darah setelah \pm 5 hari untuk mengetahui kadar glukosa darah $\geq 200 \mathrm{mg} / \mathrm{dl}$. Selama 5 hari, tikus diberi pakan standar AIN-93 M. Pada hari ke 9 dilakukan pemeriksaan glukosa darah preprandial. Setelah itu, kelompok perlakuan diberi formula enteral labu kuning sebanyak $20 \mathrm{~g} / \mathrm{kg}$ berat badan sedangkan kelompok kontrol diberi formula enteral komersial berupa diabetasol sebanyak 20 $\mathrm{g} / \mathrm{kg}$ berat badan. Setelah 2 jam pemberian, dilakukan pengambilan darah kembali untuk mengetahui glukosa darah postprandial. Berikut alur kerja penelitian:

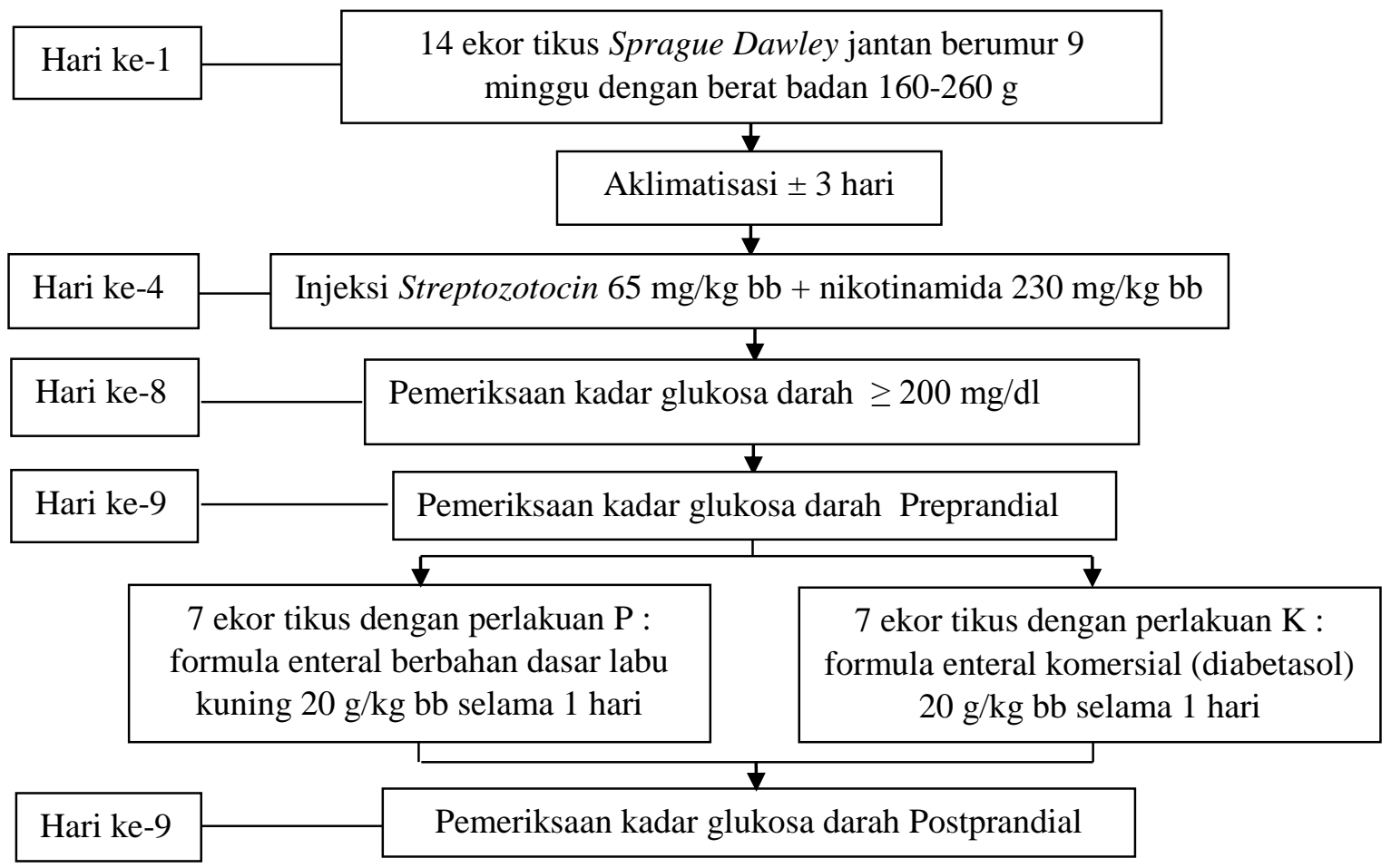

Gambar 1. Alur kerja penelitian

Pengambilan darah melalui plexus mikrokapiler sebanyak 0,5 ml per ekor. Kemudian retroorbitalis dengan menggunakan tabung dilakukan pemeriksaan glukosa darah dengan 
metode enzimatis GODPAP secara spektrofotometri, dimana darah yang telah diambil di sentrifuge dengan kecepatan 3000 rpm selama 10 menit lalu diambil serumnya dan dimasukkan ke dalam stardust sehingga didapatkan kadar glukosa darah pre-postprandial tikus dalam satuan $\mathrm{mg} / \mathrm{dl}$.

Data yang terkumpul merupakan data primer hasil pemeriksaan glukosa darah. Hasilnya berupa kadar glukosa darah kelompok perlakuan dan kelompok kontrol serta glukosa darah preprandial dan glukosa darah 2 jam postprandial. Data tersebut diuji normalitasnya menggunakan uji Shapiro wilk, kemudian dilakukan uji independent $t$ test untuk mengetahui kadar glukosa darah preprandial, postprandial dan $\Delta$ kelompok perlakuan dan kelompok kontrol. ${ }^{15}$

\section{HASIL}

Penelitian tentang pengaruh pemberian formula enteral labu kuning terhadap kadar glukosa darah postprandial tikus diabetes melitus telah dilaksanakan. Sebelumnya dilakukan uji kandungan gizi formula enteral labu kuning.
Tabel 2. Hasil Analisis Kandungan Gizi Formula Enteral Labu Kuning/100 gram

\begin{tabular}{lc}
\hline \multicolumn{1}{c}{ Kandungan } & Hasil Analisis \\
\hline Protein & $7,4 \%$ \\
\hline Lemak & $9,7 \%$ \\
\hline Karbohidrat & $71,5 \%$ \\
\hline Abu & $3,3 \%$ \\
\hline Air & $7,9 \%$ \\
\hline Serat Kasar & $8,6 \%$ \\
\hline Viskositas & $1494 \mathrm{cP}$ \\
\hline Energi & $404 \mathrm{kkal}$ \\
\hline Densitas energi & $0,96 \mathrm{kkal} / \mathrm{ml}$ \\
\hline
\end{tabular}

Selama penelitian terdapat 1 ekor tikus yang tereksklusi dalam kelompok perlakuan dikarenakan berat badan tidak memenuhi syarat inklusi, sehingga jumlah subjek penelitian sebesar 13 ekor.

Kadar glukosa darah tikus diabetes melitus dihitung pada saat preprandial dan 2 jam postprandial. Hasil rerata kadar glukosa darah masing-masing kelompok dapat dilihat pada tabel berikut.

Tabel 3. Pengaruh pemberian formula enteral terhadap kadar glukosa darah

\begin{tabular}{|c|c|c|c|}
\hline \multirow{3}{*}{$\begin{array}{c}\text { Glukosa } \\
\text { Darah }\end{array}$} & Kontrol & Perlakuan & \multirow{2}{*}{$p^{a}$} \\
\hline & $\mathrm{n}=7$ & $n=6$ & \\
\hline & \multicolumn{2}{|c|}{ Rerata $( \pm$ SD) } & \\
\hline preprandial & $212.67( \pm 5.94)$ & $218.13( \pm 8.48)$ & 0.201 \\
\hline postprandial & $221.16( \pm 5.71)$ & $223.22( \pm 8.21)$ & 0.605 \\
\hline$\Delta$ & $8.48( \pm 0.78)$ & $5.09( \pm 0.31)$ & $0.000 *$ \\
\hline
\end{tabular}

Ket.
Preprandial :pengukuran kadar glukosa darah sebelum makan
Postprandial :pengukuran kadar glukosa darah setelah 2 jam makan
$*$ Berbeda bermakna dengan kelompok kontrol
${ }^{a}$ Independent t-test

Tabel 3 menunjukkan terdapat perbedaan yang bermakna antara $\Delta$ glukosa darah kelompok perlakuan dan kelompok kontrol ( $\mathrm{p}<0.05)$, sedangkan kadar glukosa darah preprandial dan postprandial 2 kelompok tidak terdapat perbedaan bermakna ( $p>0.05$ ). Rerata kadar glukosa darah postprandial pada kelompok perlakuan yaitu 223.22 $( \pm 8.21) \mathrm{mg} / \mathrm{dl}$, sedangkan untuk kelompok kontrol tidak lebih besar dari kelompok perlakuan yaitu $221.16( \pm 5.71) \mathrm{mg} / \mathrm{dl}$.

\section{PEMBAHASAN}

\section{Kandungan Zat Gizi Formula Enteral Berbahan Dasar Labu Kuning}

Analisis kandungan zat gizi formula enteral labu kuning per 100 gram telah ditunjukkan pada tabel 2. Kandungan gizi formula enteral labu kuning per 60 gram yaitu 242,4 kkal, 4,5 gram protein, 6 gram lemak, 42,9 g karbohidrat, dan 5,1 gram serat kasar. Sedangkan kandungan gizi formula diabetasol per 60 gram sebesar 260,1 kkal, 9,9 gram protein, 6,9 gram lemak, 39 gram karbohidrat dan 3,9 gram serat kasar.

Kandungan protein dalam formula enteral labu kuning $<20 \%$ total kalori, sehingga tidak termasuk dalam formula tinggi protein. ${ }^{5}$ Hal ini dikarenakan sumber protein yang digunakan hanya berasal dari protein nabati.

Kriteria makanan enteral tinggi lemak sebesar > 40\% total kalori. ${ }^{5}$ Sedangkan formula enteral cukup lemak apabila mengandung 30-40 \% total kalori. ${ }^{7}$ Kandungan lemak pada formula enteral labu kuning termasuk rendah karena $<30 \%$. Lemak dalam formula enteral labu kuning ini berasal dari minyak kedelai. 
Jumlah karbohidrat untuk formula enteral standar umumnya $40-60 \%$ total kalori. ${ }^{7}$ Sedangkan kandungan karbohidrat dalam formula enteral labu kuning yaitu $70 \%$ total kalori. Jika dibandingkan dengan diabetasol, karbohidrat pada formula enteral labu kuning lebih tinggi. Tingginya persentase karbohidrat pada formula enteral labu kuning mengakibatkan persentase kandungan zat gizi protein dan lemak rendah. ${ }^{16}$

Kandungan serat kasar yang terdapat pada formula enteral labu kuning sebesar 5,1 gram per 60 gram. Dibandingkan diabetasol, kandungan serat ini lebih tinggi. Kebutuhan serat bagi penderita DM sebesar 25 g/hari, ${ }^{1}$ namun sebaiknya penderita diberi tambahan serat larut guna mengendalikan absorpsi glukosa. Diketahui pada labu kuning memiliki kandungan serat larut pektin sehingga diperkirakan dapat mengendalikan absorpsi glukosa. ${ }^{17}$

Kandungan energi didapat dari $4 \mathrm{kkal} / \mathrm{g}$ protein $+9 \mathrm{kkal} / \mathrm{g}$ lemak $+4 \mathrm{kkal} / \mathrm{g}$ karbohidrat. Kemudian densitas energi dapat diketahui dengan membagi kandungan energi dengan volume. Kandungan energi formula enteral labu kuning sebesar 242,4 kkal/60 gram. Energi ini tidak lebih besar dari kandungan energi formula diabetasol yaitu 260,1 kkal/60 gram. Sedangkan densitas energi formula enteral labu kuning $0,96 \mathrm{kkal} / \mathrm{ml}$. Syarat densitas energi untuk formula enteral yaitu \pm $0,5-2,0 \mathrm{kkal} / \mathrm{mL} .{ }^{7}$ Sehingga formula enteral labu kuning sudah memenuhi syarat.

Viskositas formula enteral labu kuning sebesar 1494 cP. Hasil ini mengartikan bahwa viskositas formula enteral labu kuning sesuai syarat tingkat kekentalan yaitu berkisar $800-1500 \mathrm{cP}$. Viskositas formula enteral berbahan dasar labu kuning ini tidak jauh berbeda dengan formula enteral berbasis labu kuning dan telur bebek yakni $1334,54 \mathrm{cP} ; 1428,32 \mathrm{cP} ; 1551,34 \mathrm{cP} .{ }^{18}$

\section{Pengaruh Formula Enteral terhadap Kadar Glukosa Darah Postprandial}

Berdasarkan tabel 3 dapat dilihat bahwa rerata kadar $\Delta$ glukosa darah kelompok perlakuan mengalami perbedaan yang bermakna yakni sebesar $5.09( \pm 0.31) \mathrm{mg} / \mathrm{dl}$. Perbedaan yang bermakna juga terjadi pada kadar $\Delta$ glukosa darah kelompok kontrol yaitu $8.48( \pm 0.78) \mathrm{mg} / \mathrm{dl}$. Terlihat angka penurunan rerata $\Delta$ kadar glukosa darah kelompok kontrol lebih besar dibandingkan kelompok perlakuan. Hal ini dikarenakan telah adanya aktifitas hipoglikemik pada formula enteral labu kuning, yaitu kandungan polisakarida.

Berdasarkan penelitian sebelumnya, senyawa aktif dari karakteristik hipoglikemik labu kuning terdapat pada daging buah dan biji yang sebelumnya telah mengalami proses ekstraksi. ${ }^{19}$ Proses yang umum dilakukan adalah dengan ekstraksi enzimatis. Dilaporkan ekstraksi enzimatis yang dilakukan pada buah labu kuning mampu mengaktifkan kandungan polisakarida khususnya pektin. ${ }^{10,19}$ Ekstraksi enzim juga menjadikan kandungan pektin lebih banyak dibandingkan ekstraksi menggunakan asam dengan pemberian asam klorida maupun asam sitrat. ${ }^{19,20}$ Hal ini diperkuat dengan pernyataan bahwa pektin akan berkurang kelarutannya jika dicampurkan dengan $\mathrm{pH}$ asam. $^{20}$ Walaupun dilaporkan ekstrak labu kuning dapat mengaktifkan senyawa polisakarida, serbuk labu kuning juga disebutkan dapat meningkatkan insulin plasma dan menurunkan glukosa darah secara signifikan. ${ }^{21}$

Polisakarida merupakan polimer karbohidrat yang kompleks. ${ }^{20}$ Polisakarida pada labu kuning dilaporkan bersifat hipoglikemik, dan dari suatu penelitian disebutkan bahwa polisakarida pada labu kuning dapat menekan peningkatan glukosa darah dibandingkan glibenclamide. Pemberian $1000 \mathrm{mg} / \mathrm{kg}$ berat badan polisakarida kepada tikus diabetes terkandung 41,21\% polisakarida dan $10,13 \%$ kandungan protein, serta $9,46 \%$ pektin yang berperan mengurangi kadar glukosa darah..$^{22}$ Selain itu, pemberian polisakarida labu kuning sebanyak $200 \mathrm{mg} / \mathrm{kg}$ berat badan pada tikus diabetes akan memberikan dampak baik terhadap penurunan glukosa darah pada 7 jam setelah pemberian. ${ }^{23}$

Polisakarida yang diikat oleh protein di labu kuning dapat disebut sebagai agen antidiabetes dimana dapat meningkatkan kadar toleransi glukosa, dan mengurangi glukosa darah. ${ }^{24}$ Semakin tinggi kadar polisakarida yang diikat oleh protein, semakin baik efek labu kuning dalam menurunkan kadar glukosa darah (hipoglikemia). ${ }^{25}$ Hal ini diperkuat dengan penelitian pemberian polisakarida yang diikat oleh protein sebanyak 500 dan 1000 $\mathrm{mg} / \mathrm{kg}$ berat badan dapat meningkatkan serum insulin, meningkatkan toleransi glukosa, dan menurunkan glukosa darah pada 2 jam setelah makan, akan tetapi penurunan paling baik terdapat pada dosis $1000 \mathrm{mg} / \mathrm{kg}$ berat badan. ${ }^{22}$

Pektin merupakan salah satu kandungan polisakarida yang berkontribusi sebagai serat larut. Pektin tersusun oleh galaktosa, asam galakturonat, glukosa, rhamnosa, arabinosa, dan xylosa. ${ }^{26}$ Asam galakturonat pada pektin terdiri dari $\pm 70 \%$. Pektin banyak ditemukan pada sayur dan buah. Pektin memiliki sifat mampu menahan air, dapat membentuk gel, dan dapat menunda waktu pengosongan lambung serta mengikat glukosa sehingga kecepatan absorpsi glukosa di usus halus 
berkurang. ${ }^{11}$ Selanjutnya pektin akan menimbulkan rasa kenyang yang lama dan akan menekan nafsu makan. ${ }^{26}$ Pektin dilaporkan memiliki sifat mampu mengontrol tingkat glikemik serta mengurangi kebutuhan insulin, sehingga peningkatan glukosa darah postprandial dapat dikendalikan. ${ }^{9}$ Oleh karenanya, pektin dibutuhkan bagi penderita DM.

Rerata kadar glukosa darah postprandial kelompok perlakuan maupun kelompok kontrol diketahui tidak memiliki perbedaan yang nyata $(\mathrm{p}=0.605)$ yakni rerata untuk kelompok perlakuan sebesar $223.22( \pm 8.21) \mathrm{mg} / \mathrm{dl}$ sedangkan kelompok kontrol sebesar $221.16( \pm 5.71) \mathrm{mg} / \mathrm{dl}$. Walaupun tidak terdapat perbedaan yang nyata, kadar glukosa darah postprandial kelompok perlakuan lebih tinggi dikarenakan jumlah karbohidrat lebih besar dari yang direkomendasikan. Berdasarkan hal tersebut, dibutuhkan carbohydrate counting bagi penderita diabetes agar dapat menjaga kadar glukosa darah sekaligus meningkatkan kontrol glikemik, salah satunya dengan monitoring glukosa darah postprandial. ${ }^{27}$ Glukosa darah postprandial dapat meningkat jika konsumsi karbohidrat berlebih. Rekomendasi konsumsi karbohidrat bagi penderita diabetes umumnya sebesar $45-65 \%$ total kalori. ${ }^{28}$ Selain memperhatikan jumlah konsumsi karbohidrat, penderita juga harus memperhatikan indeks glikemik bahan pangan yang akan dikonsumsi.

Jumlah insulin yang diproduksi penderita DM tidak mencukupi kebutuhan untuk menekan kelebihan glukosa darah postprandial. Oleh karenanya kadar glukosa darah postprandial terganggu. Glukosa darah postprandial yang berlebih dapat mengakibatkan peningkatan stress oksidatif pada sel $\beta$ pankreas sehingga mengalami penurunan fungsi secara perlahan. Akibatnya tubuh akan mengalami hiperglikemia dan akan terjadi penurunan respon rangsangan terhadap sekresi insulin. Selanjutnya hiperglikemia akan menginduksi apoptosis sel $\beta$ pankreas. Jika seseorang telah mengalami keadaan tersebut karena jumlah glukosa yang berlebih, ia akan menderita glukotosisitas. ${ }^{29}$

Respon glukosa darah postprandial terjadi akibat sekresi hormon inkretin berupa glucosedependent insulinotropic polypeptide (GIP) dan glucagon like peptide-1 (GLP-1) di saluran pencernaan. ${ }^{30}$ Setelah disekresikan, hormon GLP-1 dan GIP akan berikatan dengan reseptornya masingmasing untuk kemudian menstimulasi pelepasan insulin pada sel $\beta$ pankreas. Hormon GLP-1 mengandung peptida yang tidak hanya menstimulasi sekresi insulin pankreas namun juga memiliki aktifitas insulinotropic, meningkatkan efektivitas glukosa, menghambat sekresi glukagon dan memperlambat waktu pengosongan lambung sehingga meningkatkan rasa kenyang dan mengurangi nafsu makan. ${ }^{29}$

Efek inkretin berperan 30-60 \% terhadap sekresi insulin setelah makan. Akan tetapi, efek inkretin pada penderita DM tidak sama pada orang normal. Efek tersebut akan berkurang bahkan menghilang pada penderita DM karena telah terjadi gangguan pada sel $\beta$ pankreas dalam memproduksi insulin. Oleh karenanya terkadang penderita DM diberi pengobatan berupa pemberian hormon GLP1 eksogen untuk memperbaiki keadaan tersebut. ${ }^{30}$

Penyebab lain tidak terdapat perbedaan yang signifikan pada glukosa darah postprandial karena peningkatan glukosa darah postprandial merupakan respon umum yang terjadi setelah makan, termasuk penderita diabetes. Namun yang membedakan tinggi rendahnya peningkatan tersebut disebabkan beberapa faktor. Diabetasol memiliki kandungan indeks glikemik yang rendah, yakni 31 sehingga peningkatan laju glukosa darah postprandial terjadi secara perlahan. Selain itu, daging buah labu kuning juga mengandung glukosa, sehingga peningkatan glukosa darah postprandial yang lebih tinggi dibandingkan diabetasol disebabkan akibat keberadaan glukosa tersebut.

Tempe merupakan makanan olahan kedelai yang memiliki tinggi protein. Kadar protein yang tinggi dalam tempe tersebut mampu mengurangi laju pergerakan usus sehingga penyerapan glukosa terhambat. Tempe memiliki kandungan asam amino esensial seperti valin, leusin, isoleusin, dan lisin. ${ }^{31}$ Kandungan asam amino esensial leusin dilaporkan dapat menurunkan glukosa darah melalui rangsangan pelepasan hormon di saluran pencernaan seperti GLP-1 dan GIP yang berfungsi mensekresikan insulin sehingga akan terjadi efek hipoglikemik.

Penelitian ini merupakan penelitian awal tentang pengaruh produk makanan dalam bentuk formula enteral terhadap kadar glukosa darah postprandial sehingga belum terdapat dasar tentang dosis yang tepat.

\section{SIMPULAN}

Formula enteral berbahan dasar labu kuning mengandung rendah protein, rendah lemak, energi, densitas energi, dan viskositas yang cukup, namun tinggi karbohidrat. Pemberian formula enteral labu kuning sebanyak $20 \mathrm{~g} / \mathrm{kg}$ berat badan tidak memiliki pengaruh yang signifikan terhadap kadar glukosa darah postprandial tikus diabetes melitus. Akan tetapi, berpengaruh nyata terhadap kadar $\Delta$ glukosa darah. 


\section{DAFTAR PUSTAKA}

1. American Diabetes Association. Diagnosis and Classification of Diabetes Melitus. Diabetes Care Jan 2014;37 Suppl 1:S81-90.

2. Wild S, Roglic G, Green A, Sicree R, King H. Global prevalence of diabetes: estimates for the year 2000 and projections for 2030. Diabetes Care 2004;27(5):1047-53.

3. Kementerian Kesehatan RI. Riset Kesehatan Dasar : Riskesdas 2013. Indonesia: Kementerian Kesehatan RI. 2013.

4. International Diabetes Federation. Guideline for Management of Postmeal Glucose in Diabetes. International Diabetes Federation. 2011.

5. Lochs H, Allison SP, Meier R, Pirlich M, Kondrup $\mathrm{J}$, Schneider St, et al. Introductory to the ESPEN Guidelines on Enteral Nutrition : Terminology, Definitions and General Topics. Clinical Nutrition 2006; 25:180-186.

6. ASPEN. Enteral Nutrition Practice Recommendations. JPEN J Parenter Enteral Nutr April 2009; 33(2):1-46.

7. Rolfes SR, Pinna K, Whitney E. Understanding Normal and Clinical Nutrition. 8th ed. USA:Wadsworth Cengage Learning. 2006. p. 113115; 663-667.

8. Liu Y, Jin H, Xu ZQ, Nan WK, Wang T, Cheng YY. Effects of pumpkin polysaccharides on blood glucose and blood lipids in diabetic rats. Zhongguo Yingyong Shenglixue Zazhi 2006; 22(3):358-61.

9. Adams GG, Imran S, Wang S, Mohammad A, Kok S, Gray DA, et al. The hypoglycaemic effect of pumpkins as anti-diabetic and functional medicines. Food Research International 2011; 44: 862-867.

10. Zhang Y, Chen P, Zhang Y, Jin H, Zhu L, Li J, et al. Effects of polysaccharide from pumpkin on biochemical indicator and pancreatic tissue of the diabetic rabbits. Intern Journ of Bio Macro 2013;62:574-581.

11. Guillon F, Champ M. Structural and physical properties of dietary fibres, and consequences of processing on human physiology. Food Research International 2000;33:233-245.

12. WHO Regional Office for the Western Pasific Manila. Research guidelines for evaluating the safety and efficacy of herbal medicines. 1993.

13. Khasanah Y, Ariani RD, Angwar M, Nuraeni T. In Vivo Study on Albumin and Total Protein in White Rat (Rattus norvegicus) after Feeding of Enteral Formula from Tempe and Local Food. Procedia Food Sci 2015; 3: 274-279.

14. Reeves PG, Nielson FH, Fahey GC. AIN-93 Purified Diets for Laboratory Rodents : Final Report of the American Institute of Nutrition Ad Hoc Writing Committee on the Reformation of the AIN-76A Rodent Diet. J Nutr 1993; 1939-1951.

15. Dahlan MS. Statistik untuk kedokteran dan kesehatan. Jakarta : Salemba Medika. 2011. p. 6280 .
16. Bastian F, Ishak E, Tawali B, Bilang M. Daya Terima dan Kandungan Zat Gizi Formula Tepung Tempe dengan Penambahan Semi Refined Carrageenan (SRC) dan Bubuk Kakao. Jurnal Aplikasi Teknologi Pangan 2013; 2 (1): 5-8.

17. Hartono A. Terapi Gizi \& Diet Rumah Sakit. Edisi 2. Jakarta : EGC. 2004. p. 202-215.

18. Pratiwi LE, Noer ER. Analisis Mutu Mikrobiologi dan Uji Viskositas Formula Enteral berbasis Labu Kuning (Cucurbita moschata) dan Telur Bebek. Journal of Nutrition College 2014; 3(4): 951-957.

19. Ptichkina NM, Markina OA, Rumyantseva GN. Pectin extraction from pumpkin with the aid of microbial enzymes. Food Hydrocolloids 2008; 22: 192-195.

20. Tomasik P. Chemical and Functional Properties of Food Saccharides. CRC Press. New York. 2004.

21. Ju L, Chang D. Hypoglycemic effect of pumpkin powder. Journal of Harbin Medicine 2001; 21(1): 56.

22. Li Q, Fu CL, Rui YK, Hu G, Cai T. Effects of protein-bound polysaccharide isolated from pumpkin on insulin in diabetic rats. Plant Foods for Human Nutrition 2005; 60: 13-16.

23. Jin H, Zhang Y J, Jiang J X, Zhu L Y, Chen P, Li J, et al. Studies on the extraction of pumpkin components and their biological effects in blood glucose of diabetic mice. J Food and Drug Analysis 2013; 184-189.

24. $\mathrm{Gu} \mathrm{M}, \mathrm{Li} \mathrm{D}$. Pumpkin hypoglycaemic active ingredients progress in pharmacological research. Journal of Medical Research 2008; 37(5): 15-16.

25. Shi Y, Xiong X, Cao J, Kang M. Effect of pumpkin polysaccharide granules on glycemic control in type 2 diabetes. Cent South Pharm 2003;1(5):275-276.

26. Willats WGT, Knox JP, Mikkelsen JD. Pectin: new insights into an old polymer are starting to gel. Trends in Food Sci \& Tech 2006;17: 97-104.

27. Kulkarni KD. Carbohydrate Counting: A Practical Meal-Planning Option for People with Diabetes. Clinical Diabetes 2005; 23(3): 120-122.

28. PERKENI. Konsensus Pengelolaan dan Pencegahan Diabetes Melitus Tipe 2 di Indonesia. Perkumpulan Endokrinologi Indonesia. 2011.

29. Rendell MS, Jovanovic L. Targeting postprandial hyperglicemia. Metabolism Clinical and Experimental 2006; 55: 1263-1281.

30. Gavin JR. Pathophysiologic Mechanism of Postprandial Hyperglycemia. Am J Cardiol 2001;88 (6A):4H-8H.

31. Utama CS, Estiningdriati, Yunianto VW, Murningsih W. Pengaruh Penambahan Aras Mineral pada Fermentasi Sorghum dengan Ragi Tempe terhadap Kecernaan Nutrien pada Ayam Petelur. Animal prod 2007;9(1):14-17. 